\title{
Duckweed: The hidden treasure
}

\author{
Sasinath Jha and Bindu Pokharel (Bhattarai)* \\ Department of Botany, Post Graduate Campus, Tribhuvan University \\ Biratnagar, Nepal \\ *E-mail: bindupokharel@hotmail.com
}

\begin{abstract}
In recent years, the tiny aquatic angiospermic plants 'duckweeds' have become prominent because they provide high protein animal feed, organic fertilizer, bio-fuel; control mosquitoes; and, have great applicability in wastewater purification, toxicity testing, and in basic research and evolutionary model system. In the aforesaid context, this presentation deals in brief with general characteristics, distribution, environmental requirements, aquaculture, and some uses of duckweeds.
\end{abstract}

Key words: Productivity, nutritive value, wastewater treatment.

\section{Introduction}

Duckweeds are the smallest, fastest growing, and the simplest flowering aquatic plants which float on or just below the surface of nutrient-rich still or slow moving bodies of fresh and slightly brackish waters. They are monocotyledons belonging to the family Lemnaceae, although they are also classified as the subfamily Lemnoideae within the family Araceae (ShehMay et al. 2004). Duckweed consists of five genera: Landoltia, Lemna, Spirodela, Wolffia and Wolffiella. However, the most commonly available species belong to the three genera Lemna, Spirodela and Wolffia (Table 1, Figs. 1 and 2). The species of Lemnaceae are found in all possible combinations with each other and other floating plants.

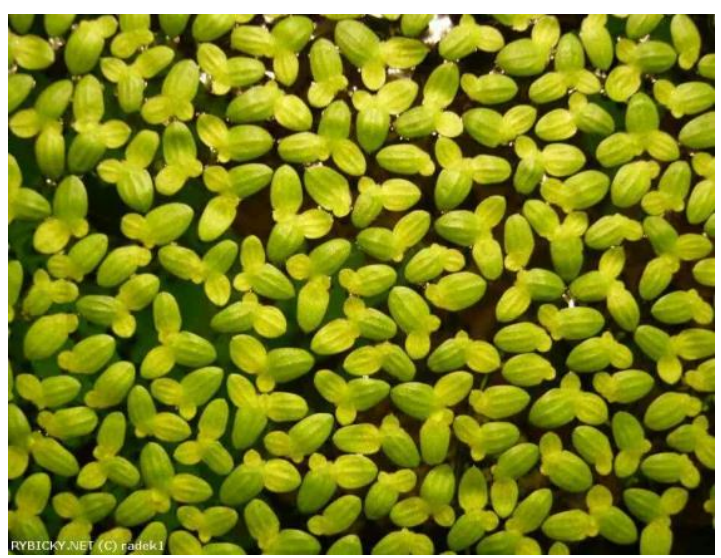

Figure 1. Lemna aequinoctialis

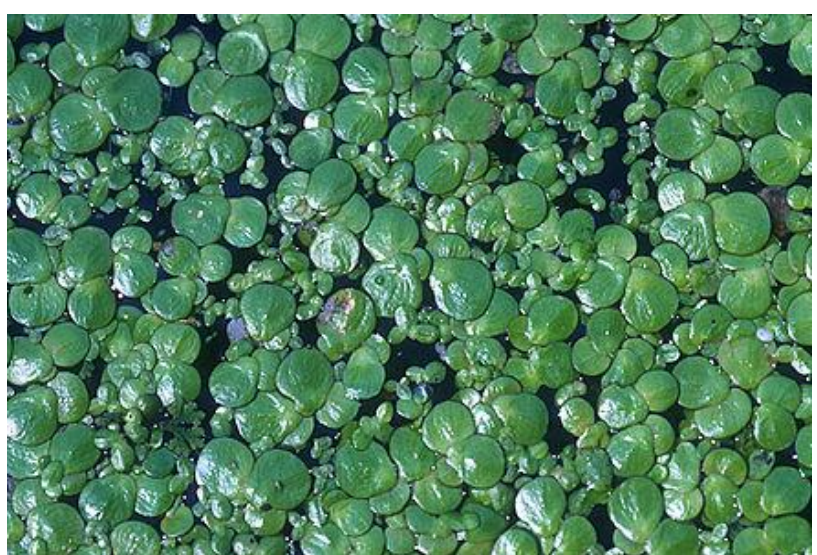

Figure 2. Spirodela polyrhiza

These plants are very simple, lacking an obvious stem or leaves. The plant body is a few cells thick thalloid frond without any root (Wolffia, Wolffiella) or may have one (Lemna) or more adventitious roots (Landoltia, Spirodela) devoid of root hairs. The bulk of the frond is composed of chlorenchymatous cells separated by large intercellular spaces that are filled with air and provide buoyancy. Some cells of Lemna and Spirodela have needle-like raphides composed of calcium oxalate. 
Table 1. Duckweeds of the South Asia [modified from Cook (1996)]

\begin{tabular}{|c|c|c|c|c|}
\hline Species & \begin{tabular}{|c|} 
Frond \\
\end{tabular} & Root & Seed & \begin{tabular}{|c|} 
Habitat and distribution \\
\end{tabular} \\
\hline $\begin{array}{l}\text { Lemna } \\
\text { aequinoctialis } \\
\text { Welwitsch }\end{array}$ & $\begin{array}{l}\text { Flattened (leaf-like), 1-6.5 } \\
\text { mm long, } 0.8-4.5 \mathrm{~mm} \\
\text { wide, floating }\end{array}$ & $\begin{array}{l}\text { Solitary, up } \\
\text { to } 3.5 \mathrm{~cm} \\
\text { long, root } \\
\text { cap sharply } \\
\text { pointed }\end{array}$ & \begin{tabular}{|l|}
$1 /$ fruit, \\
$0.45-0.8$ \\
$\mathrm{~mm}$ \\
long
\end{tabular} & $\begin{array}{l}\text { Eutrophic water bodies like roadside } \\
\text { pools, ditches, village ponds, paddy } \\
\text { fields, sluggish canals, etc.; often } \\
\text { grow together with Spirodela and/or } \\
\text { Wolffia; Pak, Nep, Ban, Mya, SL, Ind } \\
\text { (AN, AP, AS, BH, DL, GJ, HP, JH, } \\
\text { JK, KL, KT, MH,PJ,RJ,UK,UP, WB) }\end{array}$ \\
\hline Lemna gibba L. & $\begin{array}{l}\text { Flattened, } 4 \mathrm{~mm} \text { thick, } 1- \\
8 \mathrm{~mm} \text { long, } 0.8-6 \mathrm{~mm} \\
\text { wide, floating }\end{array}$ & $\begin{array}{l}\text { Solitary, }>3 \\
\text { mm long, } \\
\text { root cap } \\
\text { rounded }\end{array}$ & \begin{tabular}{|l|}
$1-5 /$ \\
fruit, \\
$0.7-0.9$ \\
mm long \\
\end{tabular} & $\begin{array}{l}\text { Mesotrophic to eutrophic water; Pak, } \\
\text { Ind (GJ, JK, PJ) }\end{array}$ \\
\hline Lemna minor $\mathrm{L}$. & $\begin{array}{l}\text { Flattended, } 1-8 \mathrm{~mm} \text { long, } \\
0.6-5 \mathrm{~mm} \text { wide, floating }\end{array}$ & $\begin{array}{l}\text { Solitary, }>3 \\
\text { mm long, } \\
\text { root cap } \\
\text { rounded }\end{array}$ & \begin{tabular}{|l|}
$1 /$ fruit, \\
$0.7-1$ \\
$\mathrm{~mm}$ \\
long
\end{tabular} & $\begin{array}{l}\text { Mesotrphic to eutrophic water; cooler } \\
\text { regions of Pak, Nep, Ind (HP, JK, SK, } \\
\text { UK) }\end{array}$ \\
\hline $\begin{array}{l}\text { Lemna tenera } \mathrm{S} . \\
\text { Kurz }\end{array}$ & $\begin{array}{l}\text { Flattened, } 3.5-9 \mathrm{~mm} \text { long, } \\
1.2-3 \mathrm{~mm} \text { wide, } \\
\text { submerged }\end{array}$ & \begin{tabular}{|l|} 
Solitary, \\
$2.5 \mathrm{~mm}$ \\
long, root \\
cap \\
rounded \\
\end{tabular} & - & Humid warm region of Mya \\
\hline $\begin{array}{l}\text { *Lemna trisulca } \\
\text { L. }\end{array}$ & $\begin{array}{l}\text { Flattened, } 3-15 \mathrm{~mm} \text { long, } \\
1-5 \mathrm{~mm} \text { wide, submerged } \\
\text { except when flowering- } \\
\text { fruiting }\end{array}$ & \begin{tabular}{|l|} 
Solitary, \\
$2.5 \mathrm{~mm}$ \\
long, root \\
cap pointed \\
\end{tabular} & $\begin{array}{l}\text { 1/ fruit, } \\
0.6-1 \\
\mathrm{~mm} \\
\text { long }\end{array}$ & $\begin{array}{l}\text { Mesotrophic cooler water (sheltered } \\
\text { between emergent reeds); Pak, Ban, } \\
\text { Ind (JK, MN, RJ, UK, WB) }\end{array}$ \\
\hline $\begin{array}{l}\text { *Lemna } \\
\text { turionifera } \\
\text { E. Landolt }\end{array}$ & $\begin{array}{l}\text { Flattened, } 2 \mathrm{~mm} \text { thick, } \\
0.8-3.5 \mathrm{~mm} \text { long, } 0.8-3.5 \\
\text { mm wide, floating }\end{array}$ & $\begin{array}{l}\text { Solitary, > } \\
3 \text { cm long, } \\
\text { root cap } \\
\text { rounded }\end{array}$ & \begin{tabular}{|l|}
$1 /$ fruit, \\
$0.5-0.8$ \\
$\mathrm{~mm}$ \\
long \\
\end{tabular} & Temperate regions; Ind (HP, JK) \\
\hline $\begin{array}{l}\text { Spirodela } \\
\text { intermedia } \\
\text { W. Koch }\end{array}$ & - & $2-5$ & - & $\begin{array}{l}\text { Native of tropical and subtropical } \\
\text { South America; introduced in Ind } \\
\text { (DL) }\end{array}$ \\
\hline $\begin{array}{l}\text { Spirodela } \\
\text { polyrhiza }(\mathrm{L} .) \\
\text { Schleiden } \\
\end{array}$ & $\begin{array}{l}\text { Flattened, } 1.5-10 \mathrm{~mm} \\
\text { long, } 1.5-8 \mathrm{~mm} \text { wide, } \\
\text { floating }\end{array}$ & $7-21$ & $\begin{array}{l}0.7-1 \\
\mathrm{~mm} \\
\text { long }\end{array}$ & Similar to Lemna acquinoctialis \\
\hline \begin{tabular}{|l|} 
Spirodela \\
punctata \\
(G.F.W. Meyer) \\
Thompson \\
\end{tabular} & $\begin{array}{l}\text { Flattened, } 1.5-8 \mathrm{~mm} \text { long, } \\
1-5 \mathrm{~mm} \text { wide, floating }\end{array}$ & $2-7$ & $\begin{array}{l}0.8-1 \\
\mathrm{~mm} \\
\text { long }\end{array}$ & $\begin{array}{l}\text { A native from the Southern } \\
\text { Hemisphere and East Asia; } \\
\text { naturalized in warm regions of Ind } \\
\text { (DL, MH, MN, WB) }\end{array}$ \\
\hline $\begin{array}{l}\text { Wolffia } \\
\text { angustata } \\
\text { E. Landolt }\end{array}$ & $\begin{array}{l}\text { Boat-shaped, } 0.5-0.8 \mathrm{~mm} \\
\text { long, } 0.2-0.4 \mathrm{~mm} \text { wide, } \\
\text { submerged except when } \\
\text { flowering - fruiting }\end{array}$ & - & $\begin{array}{l}0.3-0.4 \\
\mathrm{~mm} \\
\text { long }\end{array}$ & Eutrophic village ponds; Ind (WB) \\
\hline $\begin{array}{l}\text { Wolffia arrhiza } \\
\text { (L.) Horkel }\end{array}$ & $\begin{array}{l}\text { Spherical to ellipsoid, } 0.5- \\
1.5 \mathrm{~mm} \text { long, } 0.4-1.2 \mathrm{~mm} \\
\text { wide, submerged except } \\
\text { when flowering,fruiting } \\
\end{array}$ & - & $\begin{array}{l}0.4-0.5 \\
\mathrm{~mm} \\
\text { long }\end{array}$ & Cooler water; Ind (JK) \\
\hline \begin{tabular}{|l|}
$\begin{array}{l}\text { Wolffia globosa } \\
\text { (Roxb) den Harto } \\
\text { et van der Plas }\end{array}$ \\
\end{tabular} & $\begin{array}{l}\text { Ellipsoidal, } 0.4-0.8 \mathrm{~mm} \\
\text { long, 0.3-0.5 mm wide, } \\
\text { submerged }\end{array}$ & - & - & $\begin{array}{l}\text { Warm regions; Pak, Nep, Ban, Mya, } \\
\text { SL, Ind (AP, AS, BH, CG, DL, GJ, } \\
\text { KL, MP, PJ, RJ, TN, UK, UP, WB) }\end{array}$ \\
\hline \begin{tabular}{|l|l} 
Wolffia & I \\
\end{tabular} & Upper surface suborbicular & & $0.3 \mathrm{~mm}$ & Endemic to warmer regions; Pak, Ban, \\
\hline
\end{tabular}




\begin{tabular}{|l|l|l|l|l|}
\hline $\begin{array}{l}\text { microscopica } \\
\text { (Grif.) S. Kurz }\end{array}$ & $\begin{array}{l}\text { \& lower surface tapering } \\
\text { downwards, L. 0.4-1 mm, } \\
\text { W. 0.3-0.8 mm, submerge } \\
\text { except when flowering- } \\
\text { fruiting }\end{array}$ & long & Ind (AP, DL, GJ, HR, TN, UP) \\
\hline $\begin{array}{l}\text { Wolffia neglecta } \\
\text { E. Landolt }\end{array}$ & $\begin{array}{l}\text { Boat-shaped, 0.6-0.9 mm } \\
\text { long, 0.4-0.6 mm wide, } \\
\text { submerged }\end{array}$ & - & - & $\begin{array}{l}\text { Eutrophic water; endemic to Pak, SL, } \\
\text { Ind (RJ, WB) }\end{array}$ \\
\hline $\begin{array}{l}\text { Wolffiella } \\
\text { hyalina } \\
\text { Raff.-Del.) } \\
\text { Monod }\end{array}$ & $\begin{array}{l}\text { Boat- shaped, 1-3 mm } \\
\text { long, 0.8-2 mm wide, } \\
\text { submerged except when } \\
\text { flowering- fruiting }\end{array}$ & - & $\begin{array}{l}0.3-0.4 \\
\mathrm{~mm} \\
\text { long }\end{array}$ & $\begin{array}{l}\text { Native of drier regions of Africa; } \\
\text { introduced in Ind (Hyd) }\end{array}$ \\
\hline
\end{tabular}

(* = Turion forming species; Pak=Pakistan, Nep=Nepal, Ban=Bangladesh, Mya=Myanmar, SL=Sri Lanka, Ind = India: $\mathrm{AN}=$ Andaman and Nicobar, $\mathrm{AP}=$ Andhra Pradesh, $\mathrm{AS}=\mathrm{Assam}, \mathrm{BH}=\mathrm{Bihar}, \mathrm{CJ}=$ Chhattisgarh, $\mathrm{DL}=\mathrm{Delhi}$, GJ=Gujarat, HP=Himachal Pradesh, HR=Haryana, Hya=Hyderabad, JH=Jharkhand, JK=Jammu and Kashmir, $\mathrm{KL}=$ Kerala, $\mathrm{KT}=$ Karanataka, $\mathrm{MH}=$ Maharashtra, $\mathrm{MN}=$ Manipur, $\mathrm{MP}=$ Madhya Pradesh $, \mathrm{PJ}=\mathrm{Punjab}, \mathrm{RJ}=$ Rajasthan, SK = Sikkim, TN = Tamil Nadu, UK = Uttarakhand, UP = Uttar Pradesh, WB = West Bengal)

The vascular bundles in all duckweeds are greatly reduced. The upper epidermis in free-floating duckweeds is highly cutinized and is unwettable. Stomata are on the upper side in all five genera. Anthocyanin pigments similar to that in Azolla also form in a number of species of Lemnaceae. Roots of duckweeds are usually short but this depends on species and environmental conditions and varies from a few millimetres up to $14 \mathrm{~cm}$ (Leng 1999). Roots either stabilize the plant on the water surface or assist the plant to obtain nutrients where these are in dilute concentrations. They tend to lengthen as mineral nutrients in water are exhausted.

Duckweeds multiply principally through vegetative propagation by the formation of daughter fronds. New or daughter fronds are produced alternatively from two budding pouches on each side of the mother frond in Spirodela and Lemna. In Wolffia and Wolffiella only one budding pouch exists. These budding pouches are situated in Spirodela or Lemna close to where the root arises, whereas in Wolffia and Wolffiella the solitary budding pouch is located on the narrow end of the mother frond. Newly formed fronds remain attached to the mother frond during the initial growth phase and the plants therefore appear to consist of several fronds. An individual frond may produce as many as 20 daughter fronds during its lifetime, which lasts for a period of 10 days to several weeks. Generally, however, after 6 deliveries of daughter fronds, the mother frond tends to die. Duckweed colonies produced in laboratory or naturally are always spotted with brown dead mother fronds. The daughter frond repeats the history of its mother frond.

Vegetative growth in Lemna minor exhibits cycles of senescence and rejuvenation, mediated by chemicals released by the mother frond, under constant nutrient availability and consistent climatic conditions (Ashbey \& Wangermann 1949). Fronds of Lemna have a definite life span, during which, a set number of daughter fronds are produced; each of these daughter fronds is of smaller mass than the one preceding it and its life span is reduced. The size reduction is due to a change in cell numbers. Late daughter fronds also produce fewer daughters than early daughters. At the same time as a senescence cycle is occurring an apparent rejuvenation cycle, in which the short lived daughter fronds (with half the life span of the early daughters) produce first daughter fronds that are larger than themselves and their daughter fronds are also larger, and this continues until the largest size is produced and senescence starts again. The cyclic nature of a synchronized duckweed mat (all fronds of the same age) could be over at least one month as the life span of fronds from early to late daughters can be 33 or 19 days, respectively with a three-fold difference in frond rate production (Wangermann \& Ashbey 1950). 
When the aquatic ecosystem dries out or declining temperatures occur, duckweeds have mechanisms to persist until conditions return that can support growth. This occurs through late summer flowering, or the production of turions.

Although sexual reproduction is rare in duckweeds, some species, however, reproduce by producing very small unisexual and monoecious flowers and seeds in an inflorescence. In fact, the flower of the duckweed genus Wolffia is the smallest known, measuring merely $0.3 \mathrm{~mm}$ long (Landolt 1986). The inflorescence generally consists of one female (pistil) and two male flowers (stamens), but in Wolffia, there is one male and one female. The flowers are naked or surrounded by spathe. The fruit is a utricle and the seeds are smooth or ribbed. The seeds are resistant to prolonged desiccation and quickly germinate in favourable conditions.

During the season of short photoperiods or cold nights, newly developing fronds of several species of duckweed get transformed into small brown to olive green orbicular to reniform dormant bodies, called turions. In comparison to normal fronds, turions have shrunken vacuoles, smaller intercellular space, and abundant starch granules. Because the volume of intercellular space shrinks and starch increases the density of tissue, the turion can sink to the bottom of the water body where it can survive even if top of water freezes. Turions sprout under favourable conditions using the stored starch as an energy source to give rise to normal fronds capable of further multiplication. Several species survive at low temperatures without forming turions. During the winter season, their fronds are greatly reduced but remain at the water surface.

\section{Distribution}

In Lemnaceace, disseminules are complete fronds or seeds, and their dispersal occurs by water movement or through surface adhesion to waterfowls. Duckweeds are adapted to a wide variety of geographic and climatic zones and are distributed throughout the world except in waterless deserts, permanently frozen polar regions, and extremely wet areas with very high precipitation (Landolt 2006). Most species are found in moderate climates of tropical and subtropical zones. The appearances of duckweed species not previously seen in areas of Europe have been attributed to rising water temperature throughout the world from global warming (Wolff and Landolt 1994). Some duckweed appears to tolerate saline waters but they do not concentrate sodium ions in their growth. The apparent limit for growth appears to be between 0.5 and $2.5 \%$ sodium chloride for Lemna minor (Leng 1999).

\section{Environmental Requirements}

A variety of environmental factors, such as water temperature, $\mathrm{pH}$, nutrient concentration, crowding by overgrowth of the colony, competition from other plants for light and nutrients, etc., control the growth and survivability of duckweeds. Maximum, minimum and optimum requirements of some of the most important environmental parameters (temperature, $\mathrm{pH}$, conductivity, nitrogen and phosphorus) are given in Table 2 , whereas a range of other important mineral levels found in water supporting Lemnaceae is presented in Table 3.

Table 2. The most important environmental requirements of duckweed (Hasan \& Chakrabarti 2009)

\begin{tabular}{lccc}
\hline Parameters & Minimum & Maximum & Optimum \\
\hline Temperature $\left({ }^{0} \mathrm{C}\right)$ & $>0$ & 35 & $15-30$ \\
$\mathrm{pH}$ & 3.0 & 10.0 & $6.5-8.0$ \\
Conductivity $(\mu \mathrm{S} / \mathrm{cm})$ & 200 & 1090 & - \\
Nitrogen $(\mathrm{mg} / \mathrm{l} \mathrm{NH}-\mathrm{N})$ & Trace & 375 & $7-12$ \\
Phosphorus $\left(\mathrm{mg} / \mathrm{l} \mathrm{PO}_{4}-\mathrm{P}\right)$ & 0.017 & 154 & $4-8$ \\
\hline
\end{tabular}


Table 3. Range of other important mineral contents $(\mathrm{mg} / \mathrm{l})$ of water supporting Lemnaceae [modified from Landolt (1986)]

\begin{tabular}{ccc}
\hline Parameters & Absolute range & Range of 95\% of the samples \\
\hline $\mathrm{K}$ & $0.5-100$ & $1.0-30$ \\
$\mathrm{Ca}$ & $0.1-365$ & $1.0-80$ \\
$\mathrm{Mg}$ & $0.1-230$ & $0.5-50$ \\
$\mathrm{Na}$ & $1.3->1000$ & $2.5-300$ \\
$\mathrm{HCO}_{3}$ & $8-500$ & $10.0-200$ \\
$\mathrm{Cl}$ & $0.1-4650$ & $1.0-2000$ \\
$\mathrm{~S}$ & $0.03-350$ & $1.0-200$ \\
\hline
\end{tabular}

The effect of temperature on duckweed growth is affected by light intensity, i.e., as light increases, growth rates increase from 10 to $30^{\circ} \mathrm{C}$. Optimum temperature for maximum growth of most duckweed species lies between 17.5 and $30^{\circ} \mathrm{C}$ (Culley et al. 1981, Gaigher and Short 1986). Although some species can tolerate near freezing temperatures, growth rate declines at low temperature. Below $17^{\circ} \mathrm{C}$ some duckweeds show a decreasing rate of growth (Culley et al. 1981). Most species seem to die if the water temperature rises above $35^{\circ} \mathrm{C}$.

In general, water $\mathrm{pH}$ for aquatic plants is considered excellent between the range $6.5-7.5$; good between $6-6.4$ and 7.6 - 8; fair between 5.5-5.9 and 8.1-8.5; and poor when it is less than 5.5 or more that 8.6 (Stapp and Mitchell 1995). Koirala et al. (2011) observed that S. Polyrhiza colony survived in $\mathrm{pH}$ range of $4-7$ only when grown alone, but had $2-10$ range of $\mathrm{pH}$ tolerance when grown with $L$. aequinoctialis. Although duckweed survives at $\mathrm{pHs}$ between 2 and 10, it grows best only over the range of $6.5-8$. In this $\mathrm{pH}$ range ammonia in water is present largely as the ammonium ion which is the most readily absorbed $\mathrm{N}$ form. An alkaline $\mathrm{pH}$ (i.e., $\mathrm{pH}$ above 8) shifts the ammonium-ammonia balance toward the unionized state and results in the liberation of free ammonia, which is toxic to duckweed at high concentrations $\left(100 \mathrm{mg} \mathrm{NH}_{3} / \mathrm{l}\right)$.

Electrolyte conductivity gives an account of accumulation of salts (primarily chlorides and sulphates of calcium, magnesium, sodium and potassium) in water. Upadhyay et al. (2011) reported electrolyte range $24.8-184 \mu \mathrm{S} / \mathrm{cm}$ for the occurrence of $L$. aequinoctialis and S. polyrhiza in roadside pools at Biratnagar, Nepal. Zutshi and Vass (1973) found L. gibba and L. minor growing in stagnant waters rich in electrolyte ranging from 400-500 $\mu \mathrm{S} / \mathrm{cm}$. Gopal and Chamanlal (1991) reported the maximum biomass of $L$. perpusilla and S. polyrhiza from roadside pools and ditches within a electrolyte conductivity range of $650-1000 \mu \mathrm{S} / \mathrm{cm}$. Khondker et al. (1993) recorded the complete disappearance of $S$. polyrhiza by the end of May when a sharp fall in conductivity and alkalinity was observed. The electrolyte conductivity of water supporting the growth of L. perpusilla in Bangladesh reported by Islam and Khondker (1991) and Khondker et al. (1994) were $625 \mu \mathrm{S} / \mathrm{cm}$ and $200-890$ $\mu \mathrm{S} / \mathrm{cm}$, respectively. High electrolyte conductivity $(1090 \mu \mathrm{S} / \mathrm{cm})$ of water supporting the growth of L. perpusilla was also reported by Van der Does and Klink (1991) in a lemnid habitat in the Netherlands.

One of the most important factors influencing the distribution of aquatic plants is nutrient availability (Hutchinson 1975). Edwards et al. (1992) observed that pond water with less than $3 \mathrm{mg} / \mathrm{l}$ total kjeldahl nitrogen $(\mathrm{TKN})$ and $0.3 \mathrm{mg} / \mathrm{l}$ total phosphorus did not support normal growth of $L$. perpusilla and S. polyrhiza. The reason for the comparatively high nutrient demand of free-floating duckweeds resides in the fact that the nutrients are absorbed by the lower surface of the fronds which are rather small compared to that of the root hairs of other plants (Landolt and Kandeler 1987).

The value of duckweed as a feed resource for domestic animals depends on its crude protein content which seems to increase to a maximum of nearly $40 \%$ dry matter over the range from trace ammonia concentrations to $7-12 \mathrm{mg} \mathrm{N} / \mathrm{l}$ (Leng et al. 1994). Culley et al. (1981) reported 
that the TKN of water should not drop below $20-30 \mathrm{mg} / \mathrm{l}$ if the optimum production and a high crude protein content of duckweed are to be maintained. A useful indicator of whether conditions in the pond are appropriate for growth of duckweed (Lemna spp.) of high protein content is the length of the roots as there is a close negative relationship between root length and protein content of the duckweed and with the $\mathrm{N}$ content of the water. By monitoring this characteristic, the user can have an indication of the nutritive corrective measures when the length of the roots exceeds about $10 \mathrm{~mm}$ (Leng 1999).

Duckweeds prefer ammonium nitrogen $\left(\mathrm{NH}_{4}-\mathrm{N}\right)$ as a source of nitrogen and will remove it preferentially, even in the presence of relatively high nitrate concentrations. Luond (1980) demonstrated that higher growth rates were attained when nitrogen was in the $\mathrm{NH}_{4}-\mathrm{N}$ rather than the $\mathrm{NO}_{3}-\mathrm{N}$ form. In organically enriched waters, nitrogen tends to be concentrated in the $\mathrm{NH}_{4}-\mathrm{N}$ rather than the $\mathrm{NO}_{3}-\mathrm{N}$ form at $\mathrm{pH}$ levels below 9 and plant growth is equally efficient in anaerobic and aerobic waters (Said et al. 1979). In lagoons receiving organic animal wastes, the $\mathrm{pH}$ seldom exceeds 8, particularly with a full duckweed cover that suppresses phytoplankton growth (Culley et al. 1978). Urea is a suitable fertilizer and is rapidly converted to $\mathrm{NH}_{4}-\mathrm{N}$ under normal conditions.

Phosphorus is essential for rapid growth and is a major limiting nutrient after nitrogen, although its quantitative requirement for maximum growth is generally low. Fast growing duckweed in nutrient rich water is a highly efficient sink for both phosphorus and potassium; little of each, however, is required for rapid growth. Duckweeds appear to concentrate $\mathrm{P}$ up to about $1.5 \%$ of their dry weight and as such are able to grow on high $\mathrm{P}$ waters provided the $\mathrm{N}$ concentrations are maintained. The plant also appears to be able to draw on the pool of $\mathrm{P}$ in its biomass for its biochemical activities and once $\mathrm{P}$ had been accumulated it will continue to grow on waters devoid of $\mathrm{P}$. Saturation of phosphate uptake by duckweed occurs at available $\mathrm{PO}_{4} \mathrm{P}$ concentrations of 4 to $8 \mathrm{mg} / \mathrm{l}$. Rejmankova (1975) reported good growth of duckweed within the P concentrations of 6 to $154 \mathrm{mg} / \mathrm{l}$. Culley et al. (1978), working in dairy waste lagoons, achieved doubled production from 2 to 4 days at $\mathrm{P}$ concentrations in excess of $35 \mathrm{mg} / \mathrm{l}$. Reduced growth in some species occurs only when $\mathrm{P}$ values drop below 0.017 $\mathrm{mg} / \mathrm{l}$ (Luond 1980). Although vigorously growing duckweed is a highly efficient K sink, only low concentrations of $\mathrm{K}$ in water are needed to support good growth when other mineral requirements are satisfied. Most decaying plant materials would easily produce the $\mathrm{K}$ requirements of duckweed.

Most research on nutrient requirements have centred on the need for N, P and K. However, like all plants, duckweeds need an array of trace elements and have well developed mechanisms for concentrating these from dilute sources. From the experience of the Non-Government Organization PRISM (Project in Agriculture, Rural Industry, Science and Medicine) in Bangladesh, it appears that providing trace minerals through the application of crude sea salt $(9 \mathrm{~kg} / \mathrm{ha} / \mathrm{day})$ is sufficient to ensure good growth rates of duckweeds in ponded systems (Leng 1999).

\section{Aquaculture}

Unproductive marginal land along roads and paths or derelict ponds may be suitable choice to cultivate duckweed, as rental or purchase prices for such lands are usually lower than for arable soil. Additional land for fish ponds is necessary in the case of integrated duckweed-fish production in two-pond systems. The required duckweed/ fish pond area ratios of 1:1 to 2:1 are reported to provide enough duckweed for fish production (Iqbal 1999). Long narrow ponds with water depth between 20 and $50 \mathrm{~cm}$ are generally recommended to buffer heat, nutrient and $\mathrm{pH}$ extremes by dilution, and to facilitate harvesting (Gaigher and Short 1986). Duckweeds are prone to be blown into heaps by heavy winds or wave action. This allows light to penetrate the water column and would stimulate phytoplankton and algal growth. If the plants become piled up in deep layers, however, the lowest layer will be cut off from light and will eventually die (Skillicorn et al. 1993). Plants pushed from the water onto a bank will also dry out and die. To 
counteract this problem, ponds should be sited perpendicular to the common wind. In large ponds and wide canals a floating bamboo or plastic containment grid system is required to prevent the plants from drifting to the shore by the action of wind or water current. The sides of the ponds must preferably be vertical to prevent the plants from becoming stranded and at least $10 \mathrm{~cm}$ higher than the water level to accommodate heavy rains. Banana, papaya, lemon, bamboo, etc., planted on the pond embankments can serve as a protection for duckweed from wind and direct sunlight. Besides, the co-crops may generate additional income.

Rainwater collected in ponds may need a balanced NPK application which can be given as inorganic fertilizer or as rotting biomass, manure or polluted water from agriculture, sewage or industry. The ponds must be fed with effluent through furrows rather than pipes because the latter tend to become clogged. Several inlets must be provided to spread the inflowing nutrients over the pond. Urea is a suitable fertilizer, containing approximately $45 \%$ nitrogen, and is rapidly converted to ammonia under normal conditions. Muriate of potash (MP) and triple superphosphate (TSP) each in a ratio to urea of $1: 5$ work satisfactorily as sources of potassium and phosphorus, whereas crude sea salt is used as the source of trace minerals (Skillicorn et al. 1993). Application methods of the inorganic fertilizer include broadcasting, dissolving in the water column of the plot, and spraying a fertilizer solution on the duckweed mat.

A fertilizer application matrix aimed to achieve variable daily production ranging from $500-$ $1000 \mathrm{~kg}$ of fresh duckweed per hectare was developed by Project in Agriculture, Rural Industry, Science and Medicine (PRISM, an NGO) in their experimental programme at Mirzapur, Bangladesh (Table 4). Furthermore, PRISM recommended daily fertilization rates for different types of duckweed (Table 5). The application rate varies from $21-28 \mathrm{~kg} / \mathrm{ha} / \mathrm{day}$ (amounting to $>7$ tonnes/ ha/ year) with an anticipated fresh biomass yield of $900-1000 \mathrm{~kg} / \mathrm{ha} / \mathrm{day}$. The daily fertilization rate for duckweed cultivation developed by the Bangladesh Fisheries Research Institute (B F R I) is presented in Table 6. The fertilizer schedules developed by PRISM and BFRI are very similar (Tables 5 and 6), except that BFRI recommended half the dosage of inorganic fertilizer when cow dung was used at the rate of $750 \mathrm{~kg} / \mathrm{ha} /$ day.

Table 4. Daily fertilizer application matrix for duckweed cultivation (Skillicorn et al. 1993)

\begin{tabular}{ccccccc}
\hline Fertilizer & \multicolumn{6}{c}{ Daily production of fresh plants (kg/ ha) } \\
\cline { 2 - 7 } Application (kg/ ha) & $\mathbf{5 0 0}$ & $\mathbf{6 0 0}$ & $\mathbf{7 0 0}$ & $\mathbf{8 0 0}$ & $\mathbf{9 0 0}$ & $\mathbf{1 0 0 0}$ \\
\hline Urea & 10.0 & 12.0 & 14.0 & 16.0 & 18.0 & 20.0 \\
TSP & 2.0 & 2.4 & 2.8 & 3.2 & 3.6 & 4.0 \\
MP & 2.0 & 2.4 & 2.8 & 3.2 & 3.6 & 4.0 \\
Sea salt & 4.5 & 5.4 & 6.3 & 7.2 & 8.1 & 9.0 \\
\hline
\end{tabular}

Table 5. Rates of fertilizer application for duckweed cultivation (D W R P 1998)

\begin{tabular}{cccc}
\hline \multirow{2}{*}{ Duckweed } & \multicolumn{3}{c}{ Rate of application (kg/ ha/ day) } \\
\cline { 2 - 4 } & Urea & TSP & MP \\
\hline Spirodela & 20 & 4 & 4 \\
Wolffia & 15 & 3 & 4 \\
Lemna & 15 & 3 & 3 \\
\hline
\end{tabular}

Table 6. Rates of fertilizer application for duckweed cultivation (B F R I 1997)

\begin{tabular}{lcccc}
\hline \multirow{2}{*}{ Fertilizer combination } & \multicolumn{4}{c}{ Rate of application $(\mathbf{k g} / \mathbf{h a} / \mathbf{d a y})$} \\
\cline { 2 - 5 } & Urea & TSP & MP & Cow dung \\
\hline Inorganic fertilizer only & $15-20$ & $3-4$ & $3-4$ & - \\
Combination of organic- inorganic fertilizer & 7.5 & 1.5 & 1.5 & 750 \\
\hline
\end{tabular}


Any waste organic material that is readily biodegradable and has a sufficiently high nutrient content (Table 7) could be used for duckweed cultivation. The most economical sources of such waste materials are all kinds of animal manure, kitchen wastes, wastes from a wide range of food processing plants, biogas effluents, and slaughter house wastes. Solid materials, such as manure from livestock, night soil from villages, or food processing wastes, can also be mixed with water and added to ponds at suitable levels. All wastewater containing manure or night soil must undergo an initial treatment by holding it for a few days in an anaerobic pond, before using it to cultivate duckweed.

Table 7. Moisture, organic and mineral content of some organic wastes expressed in percent dry matter (Gijzen \& Khondker 1997)

\begin{tabular}{lccccccc}
\hline $\begin{array}{l}\text { Nutrient } \\
\text { Source }\end{array}$ & Moisture & $\begin{array}{c}\text { Dry organic } \\
\text { matter }\end{array}$ & $\mathbf{C}$ & $\mathbf{N}$ & $\mathbf{P}_{2} \mathbf{O}_{\mathbf{5}}$ & $\mathbf{K}_{2} \mathbf{O}$ & $\mathbf{C a O}$ \\
\hline Human faecal matter & $65-80$ & $88-97$ & 40.55 & $5-7$ & $3-5.5$ & $1-2.5$ & $4-5$ \\
Human urine & $93-96$ & $65-85$ & $11-17$ & $15-19$ & $2.5-5$ & $3-4.5$ & $4.5-6$ \\
Urban refuse & $10-60$ & $25-35$ & $12-17$ & $0.4-0.8$ & $0.2-0.5$ & $0.8-1.5$ & $4-7.5$ \\
Water hyacinth compost & $85-95$ & - & - & 1.9 & 1 & 2.9 & 4.6 \\
Cow dung (fresh) & 85 & - & - & 0.4 & 0.02 & 0.1 & - \\
Cow dung (compost) & - & - & - & 0.5 & 0.3 & 0.2 & 0.3 \\
Pig manure (fresh) & 80 & - & - & 0.5 & 0.5 & 0.45 & - \\
Poultry (fresh) & - & - & - & 1.6 & 1.5 & 0.85 & - \\
$\begin{array}{l}\text { Digester effluent charged } \\
\text { with pig manure }\end{array}$ & - & 6.5 & - & 3.4 & - & - & - \\
\hline
\end{tabular}

Sutton and Ornes (1975) and Said et al. (1979) demonstrated the necessity of periodic additions of nutrients to small duckweed culture systems receiving municipal or dairy cattle wastes. Within 1-3 weeks, there was a noticeable drop in N, P and $\mathrm{K}$ within the plants. There was a corresponding drop in crude protein as the plant nitrogen declined. In fact, due to the high nitrogen requirement of duckweed and the relative rapid loss of nitrogen from aquatic system, this nutrient tend to be limiting in ponds fed with wastewater (Gaigher and Short 1986). Large scale duckweed production therefore requires the availability of relatively large quantities of organic waste.

Algal blooms: Light penetration in the water column and subsequent competition for nutrients and space by algae can become a nuisance when the duckweed mat is incomplete due to disturbances or poor growth. Edwards et al. (1987) reported that the filamentous green alga Spirogyra bloomed in duckweed ponds fed with latrine effluent. The farmers removed the algae manually, but the algae grew rapidly, became entangled with the duckweed roots and the duckweed fronds turned in colour from green to yellow. In several ponds, duckweed stopped growing and died. Although the ponds were cleaned from dead duckweed and algae and restocked with healthy duckweed, algal blooms reoccurred in most cases.

In another study (Edwards et al. 1992), algal blooms of both filamentous algae (mostly the bluegreen alga Oscillatoria and the green alga Oedogonium) and phytoplankton (mostly the bluegreen alga Microcystis) were reported as one of the most important factors constraining growth of duckweed with septage. The former was more harmful to duckweed as it clogged and wrapped itself around plant roots, causing the fronds of duckweed to shrivel and finally die. Attempts were made to kill algae by the algicide copper sulphate at a concentration of $2 \mathrm{mg} / \mathrm{l}$. Algal growth was inhibited, but duckweed turned yellowish in colour. By changing the 
harvesting strategy, to maintain an almost complete duckweed cover on the pond surface, algal blooms did not reoccur. However, when algal infestation became severe, it was necessary to clear the pond and restock it with fresh duckweed.

Insect and fungal infestation: Though duckweed growth is reported to be less sensitive to pests and diseases compared to most other aquatic plants (Dinges 1982), insect infestation can cause severe damage and even death of the plants. Fungal infestation inhibits growth.

A study in Thailand revealed that occasional insect infestation by larvae of Nymphula (Order Lepidoptera, Family Pyralidae) and/ or by the waterlily aphid Rhopalosiphum nymphaeae (Order Homoptera, Family Aphididae) caused heavy damage to duckweed (Edwards et al. 1987). Infestation by Nymphula was more frequent than by aphids. In one case, Nymphula infestation caused the death of plants within two weeks. In the same study, fungal infestation occurred in many ponds and inhibited the growth of duckweed. The fungal infestation resulted in a leaf spot disease and was probably caused by Mylothecium, which is also a parasite of the aquatic mosquito fern, Azolla. However, farmers, who commercially cultivated duckweed in Taiwan, reported that insects cause no problems to the crops and regarded insect damage as unimportant (Edwards et al. 1987).

Application of biocides to control insect and fungal infestation of duckweed is critical due to their extremely high and rapid uptake by duckweed and possible transfer into the food chain. In this context, Zirschky and Reed (1998) opined that a mixture of several duckweed species would be less susceptible to infestations and diseases than a monoculture.

Relief of heat stress: As aforementioned, duckweed growth rapidly declines at temperatures above 31 to $35^{\circ} \mathrm{C}$, as the plants experience severe heat stress. Relief of heat stress during extremely hot days can be achieved by manual dunking (dipping the duckweed below the water surface) once a day, which is an efficient and immediate way of lowering temperatures by 5 to $10^{\circ} \mathrm{C}$. Dunking consists of agitating the whole-cultivated area by hand until all plants have been physically immersed and wetted.

Productivity: Duckweed growth is largely a function of available nutrients, temperature, light, and degree of crowding. The highest growth rate reported for Lemnaceae under optimal laboratory conditions is about 0.66 generations per day, which corresponds to a doubling time of 16 hours (D W R P 1997). Duckweed generally doubles their mass in 16 hours to 2 days under optimal nutrient availability, sunlight, and water temperature. This result in an exponential growth, at least until the plants become crowded or run out of nutrients. The rate of harvesting duckweed is important since there is a minimum biomass at which yields will decrease and an upper biomass where yield will be limited by crowding, all other variables being equal. In a study where most of the conditions for growth were unlimited, the effect of harvesting indicated that above about $1.2 \mathrm{~kg} / \mathrm{m}^{2}$ duckweed (fresh) growth decreased and below $0.6 \mathrm{~kg} / \mathrm{m}^{2}$ duckweed (fresh) biomass limited growth potential. It appeared that if $1 \mathrm{~kg}$ (fresh) duckweed/ $\mathrm{m}^{2}$ could be maintained by frequent harvesting then an extrapolated yield of 32 tonnes dry matter/ ha/ year could be produced under other non-limiting conditions (Leng et al. 1994). In an experimental programme in Bangladesh, a base Spirodela density of $600 \mathrm{~g} / \mathrm{m}^{2}$ was shown to yield incremental growth of 50 to $150 \mathrm{~g} / \mathrm{m}^{2} /$ day (Skillicorn et al. 1993). Culley and Myers (1980) obtained an annual dry weight production of 23.31 tonnes/ha with daily harvesting ranging from 10 to $35 \%$ of the standing crop each day, depending on the season. Edwards (1990) recommended 25\% harvesting of the duckweed biomass at 1-3 days intervals when duckweed growth completely covers the pond, with the remaining $75 \%$ left in the pond for further growth. 
Table 8 represents the yields of various duckweed species under different environmental conditions. The value varied widely, ranging from 9 to 38 tonnes dry matter/ha /year. This wide range of productivity may be attributed to differences in species, climatic conditions, nutrient supply and environmental conditions. Many of the reported high yields are based on extrapolated data obtained from short-term growth from small-scale experimental systems rather than potential long-term yields from commercial-sized systems. Edwards (1990) reported extrapolated yields of about 20 tonnes dry matter/ha/year of Spirodela from experiments that were carried out for periods of 1-3 months in septage-fed $200 \mathrm{~m}^{2}$ ponds in Thailand; however, the yield declined to the equivalent of about 9 tonnes dry matter/ha/year over a 6 months period. On the basis of available data (Table 8), Hasan and Chakrabarti (2009) opined that an average annual yield of around 10-20 tonnes dry matter/ha/year can be obtained from an aquatic environment where nutrients are generally not limiting and frequent harvesting is practised to avoid plant overcrowding.

Table 8. Yields of various duckweed species under different environmental conditions

\begin{tabular}{llcl}
\hline Species & Environmental condition & $\begin{array}{l}\text { Yield (dry matter } \\
\text { tonnes/ha/year) }\end{array}$ & \multicolumn{1}{c}{ Reference } \\
\hline L. minor & $\begin{array}{l}\text { Upflow Anaerobic Sludge } \\
\text { Blanket Reactor (UASB) effluent }\end{array}$ & 10.7 & $\begin{array}{l}\text { Vroon \& Weller } \\
(1995)\end{array}$ \\
\hline L. minor & Nutrient non-limiting water & 16.1 & $\begin{array}{l}\text { Reddy \& De } \\
\text { Busk (1984) }\end{array}$ \\
\hline L. perpusilla & Septage-fed pond & 11.2 & $\begin{array}{l}\text { Edwards } \text { et al. } \\
(1990)\end{array}$ \\
\hline $\begin{array}{l}\text { L. perpusilla, S. } \\
\text { polyrhiza, \& W. arrhiza }\end{array}$ & Septage from septic tank & $9.2-21.4$ & $\begin{array}{l}\text { Edwards } \text { et al. } \\
(1992)\end{array}$ \\
\hline Lemna & Domestic wastewater & 26.9 & $\begin{array}{l}\text { Zirschky \& Reed } \\
(1998)\end{array}$ \\
\hline $\begin{array}{l}\text { Lemna } \\
\text { Lemna, Spirodela \& }\end{array}$ & Sugar-mill effluent & 32.1 & $\begin{array}{l}\text { Ogburn \& } \\
\text { Ogburn (1994) }\end{array}$ \\
\hline $\begin{array}{l}\text { Wolffia } \\
\text { Lemna \& Wolffia }\end{array}$ & Fomestic wastewater & $13-38$ & $\begin{array}{l}\text { Skillicorn } \text { et al. } \\
(1993)\end{array}$ \\
\hline S. polyrhiza & Domestic waste water & $14-16$ & Edwards (1987) \\
\hline $\begin{array}{l}\text { S. polyrhiza } \\
\text { S. polyrhiza }\end{array}$ & Sewage effluent & $17-32$ & $\begin{array}{l}\text { Alaerts } \text { et al. } \\
(1996)\end{array}$ \\
\hline
\end{tabular}

Harvesting and storage: For shallow ponds, the most simple harvesting techniques include manual skimming of the plants from the pond surface with a net, or moving the floating plants to one corner of the pond with a bamboo pole and removing them with baskets. Two people were reported to require 3.5 hours for manual harvesting of duckweed from a 0.3 ha pond in Taiwan (Iqbal 1999). Large - scale harvesting in industrialized countries is carried out with mechanical harvesting machines requiring, however, deep ponds.

High moisture content of the fresh duckweed increases its handling, transport and drying costs. This fact is less important in integrated systems where fresh duckweed is fed to animals as the only feed or, in combination with other feed components. Fresh duckweed can be stored 
temporarily in a cool, humid place, such as in a small tank or pool. The fresh material, which will begin to ferment at high temperatures after a few hours, can be preserved for several days if kept cool and damp (Skillicorn et al. 1993).

The economic potential of duckweeds may not be fully realized until it can be economically reduced to a dried, compact commodity. This requires solar drying and either pelleting, powdering or other potential preservation methods like ensilaging. The waxy coating on the upper surface of duckweed plants is a good binding agent for pelleting. It can be stored for five or more years in the form of dried pellets. Sealable, opaque plastic bags are recommended for long-term storage to protect dried pellets from humidity, insects, vermin, and direct sunlight (Skillicorn et al. 1993).

Nutritive value: The entire body of duckweeds is composed of non-structural, metabolically active tissue; most photosynthesis is devoted to the production of protein and nucleic acids, making the plants very high in nutritive value. The nutritional content of duckweed is probably more dependent on the mineral concentrations of the growth medium than on the species or their geographic location (Hasan and Chakrabarti 2009). Water low in nutrients generally results in reduced nutritional content and slow growth in duckweeds.

Compared with most plants, duckweed fronds have little fibre as they do not need to support upright structures. Crude fibre content is generally lower (varying between 7-10\%) for duckweeds grown in nutrient-rich water than that grown in nutrient-poor water $(11-17 \%)$ (Leng et al. 1994). Similarly, ash content (that ranges between $12-18 \%$ in duckweeds) is also higher in duckweed colonies with slow growth.

Duckweeds are rich source of nitrogen, phosphorus, potassium and calcium (Guha 1997). The concentration of $\mathrm{N}$ and $\mathrm{P}$ in duckweed tissues depend on the amount of $\mathrm{N}$ and $\mathrm{P}$ in the water, up to a threshold concentration that has not been clearly defined. Above this threshold, there is little increase in the tissue.

When conditions are good, duckweed contains considerable protein, fat, starch and minerals, which appear to be mobilized for biomass growth when nutrient concentrations in the growth medium fall below the critical levels for growth. The crude protein content of duckweed seems to increase from trace ammonia concentrations to $7-12 \mathrm{mg} \mathrm{N} / \mathrm{l}$ when crude protein reaches a maximum of about $40 \%$ (Leng et al. 1994). Assuming a mean annual yield of 17.6 tonne dry matter/ ha / year, with a protein content of $37 \%$ dry weight, a protein production of about 6.5 tonne/ ha / year can be obtained. This per hectare protein yield is far higher than for most other crop plants, and about 10 times that of soyabean (Table 9). This remarkable value for duckweed is not only attributed to its high growth rate and high protein content, but also to the fact that the entire biomass of duckweed is used as compared to only the seeds for most crops (Gijzen and Khondker 1997). Besides, duckweed protein has a better amino acid profile than most plant proteins and more closely resembles animal protein than any other plant proteins. The levels of amino acids are very similar in the various species and all the essential amino acids are generally present. 
Table 9. Comparison of protein yields of duckweed and selected crops (Gijzen and Khondker 1997)

\begin{tabular}{lccc}
\hline Plant / Crop & $\begin{array}{c}\text { Yield (tonne dry } \\
\text { matter/ha/year) }\end{array}$ & $\begin{array}{c}\text { Crude protein } \\
\text { (\% dry weight) }\end{array}$ & $\begin{array}{c}\text { Relative protein } \\
\text { production* }\end{array}$ \\
\hline Duckweed & 17.6 & 37 & 100 \\
Soyabean & 1.59 & 41.7 & 10.2 \\
Alfalfa hay & $4.37-15.69$ & $15.9-17$ & $11.4-38.3$ \\
Peanuts & $1.6-3.12$ & 23.6 & $5.7-11.3$ \\
Cottonseed & 0.76 & 24.9 & 2.9 \\
* Relative protein production: duckweed set at 100 units $=6.51$ tonne dry matter/ ha/ year
\end{tabular}

The lipid content is lower (1.8-2.5\%) in duckweed species grown in nutrient-poor water, while it generally varies between $3-7 \%$ for duckweed grown in nutrient-rich water (Hasan \& Chakrabarti 2009). Cultured duckweed has high concentrations of trace minerals and pigments, especially $\beta$-carotene and xanthophylls (Haustein et al. 1988). Duckweeds, however, store varying amounts of calcium as calcium oxalate crystals in the vacuoles. A summary of the nutritional composition of different species grown under different environmental conditions is presented in Table 10.

\section{Use of Biomass}

Human consumption: Wolffia arrhiza has traditionally been eaten in Myanmar, Laos, and northern Thailand (Bhanthumnavin \& McCarry 1971). However, the use of Lemnaceae for human consumption has surprisingly not spread to other regions of the world. A possible explanation could be its high content of crystallized oxalic acid which has a negative effect on the taste. Another factor contributing to the low interest in duckweed as a potential food product for human consumption could be attributed to the fact that it is difficult to separate associated (pathogenic) organisms such as worms, snails, protozoa, and bacteria from the plant (Gijzen \& Khondker 1997).

Animal feed: Use of duckweed as fish feed is by far the most widespread application. Duckweeds can be fed to fish in fresh form as a sole feed or in combination with other feed ingredients. Duckweeds are also fed as a dried meal ingredient in pelleted diets. Fresh and dried duckweed are fed to grass carp, Nile tilapia, common carp, Indian major carps (rohu and mrigal), silver carp, Java barb, hybrid grass carp and hybrid tilapia.

Fresh duckweeds are fed as a sole feed (ad libitum or at restricted level) whereas dried duckweed meal is incorporated by partially replacing other conventional feed ingredients (oil cake, wheat bran, rice bran, etc.) in pelleted diets. Ad libitum feeding of fresh duckweed is mostly used for herbivorous fish. Nikolskij and Verigin (1996) reported that grass carp consumed fresh duckweed equal to their body weight over a 24 hour period. Baur and Buck (1980) reported that grass carp consumed from $85 \%$ to $238 \%$ of their body weight/ day (BW/ day) on a mixed diet of Lemna, Spirodela and Wolffia spp. Shireman et al. (1977) recorded consumption rates varying from 7.2-7.4\% BW/day on a dry weight basis (DW) while fresh duckweed (L. minima) was fed ad libitum. Since duckweed contains about $92 \%$ moisture, the dry weight feeding rates given above are equivalent to $90-92 \% \mathrm{BW} /$ day on a fresh weight basis. Hassan and Edwards (1992) studied the effect of feeding rate of L. perpusilla on the survival, growth and food conversion rate of Nile tilapia and recorded that the optimal daily feeding rates of Lemna were 5, 4 and 3\% BW/ day DW for fish of 25-44 g, 45-74 g and 75-100 g, respectively. Though carp polyculture using duckweed as the only feed input is reported to be feasible, there is some evidence that duckweed as a sole feed for fish is a diet too low in fats and 
carbohydrates. Therefore, for a balanced diet a mixture of 50-60\% (DW) duckweed and 40$45 \%$ (DW) fat and carbohydrate-rich feed has been suggested (Iqbal 1999).

Table 10. Chemical analyses of various duckweed species grown under different environment conditions

\begin{tabular}{|c|c|c|c|c|c|c|c|c|c|c|}
\hline \multirow{2}{*}{$\begin{array}{l}\text { Duckweed } \\
\text { species }\end{array}$} & \multirow{2}{*}{$\begin{array}{l}\text { Aquatic } \\
\text { environment }\end{array}$} & \multirow{2}{*}{$\begin{array}{c}\text { Mois } \\
\text {-ture } \\
(\%)\end{array}$} & \multicolumn{5}{|c|}{$\begin{array}{c}\text { Proximite composition }{ }^{1} \\
\text { (\% dry matter) }\end{array}$} & \multicolumn{2}{|c|}{$\begin{array}{l}\text { Minerals (\% } \\
\text { dry matter) }\end{array}$} & \multirow[t]{2}{*}{ Reference } \\
\hline & & & $\mathbf{C P}$ & $\mathbf{E E}$ & Ash & $\mathbf{C F}$ & NFE & $\mathbf{C a}$ & $\mathbf{P}$ & \\
\hline $\begin{array}{l}\text { L. aequinoctialis, } \\
\text { Nepal }\end{array}$ & $\begin{array}{l}\text { Low-nutrient }{ }^{2} \\
\text { roadside pool }\end{array}$ & - & 7.1 & - & - & - & - & - & 0.35 & $\begin{array}{l}\text { Koirala } \\
(2015)\end{array}$ \\
\hline L. gibba, USA & $\begin{array}{l}\text { Low-nutrient }{ }^{2} \\
\text { lagoon }\end{array}$ & - & 9.4 & 1.8 & 16.8 & 17.0 & 55.5 & 1.38 & 0.72 & $\begin{array}{l}\text { Culley et al. } \\
\text { (1981) }\end{array}$ \\
\hline $\begin{array}{l}\text { L. minor, } \\
\text { Bangladesh }\end{array}$ & $\begin{array}{l}\text { Pond, nutrient } \\
\text { status not specified }\end{array}$ & 92.0 & 14.0 & 1.9 & 12.1 & 11.1 & 60.9 & - & - & $\begin{array}{l}\text { Zaher et al. } \\
\text { (1995) }\end{array}$ \\
\hline $\begin{array}{l}\text { L. minor, } \\
\text { Bangladesh }\end{array}$ & $\begin{array}{l}\text { Ditch, nutrient } \\
\text { status not specified }\end{array}$ & 93.8 & $\begin{array}{l}20.3- \\
23.5\end{array}$ & - & - & - & - & - & - & $\begin{array}{l}\text { Majid et al. } \\
\text { (1992) }\end{array}$ \\
\hline $\begin{array}{l}\text { S. polyrhiza, } \\
\text { USA }\end{array}$ & $\begin{array}{l}\text { Low-nutrient }{ }^{2} \\
\text { lagoon }\end{array}$ & - & 13.1 & 2.5 & 13.3 & 16.1 & 55.0 & 1.21 & 0.56 & $\begin{array}{l}\text { Culley et al. } \\
(1981)\end{array}$ \\
\hline $\begin{array}{l}\text { S. polyrhiza, } \\
\text { Bangladesh }\end{array}$ & $\begin{array}{l}\text { Ditch, nutrient } \\
\text { status not specified }\end{array}$ & 95.0 & $\begin{array}{l}17.3- \\
28.4\end{array}$ & - & - & - & - & - & - & $\begin{array}{l}\text { Majid et al. } \\
\text { (1992) }\end{array}$ \\
\hline $\begin{array}{l}\text { S. polyrhiza, } \\
\text { Nepal }\end{array}$ & $\begin{array}{l}\text { Low-nutrient }{ }^{2} \\
\text { roadside pool }\end{array}$ & - & 13.3 & - & - & - & - & - & 0.32 & $\begin{array}{l}\text { Koirala } \\
(2015)\end{array}$ \\
\hline $\begin{array}{l}\text { S. punctata, } \\
\text { USA }\end{array}$ & $\begin{array}{l}\text { Low-nutrient }{ }^{2} \\
\text { lagoon }\end{array}$ & - & 10.6 & 2.3 & 14.1 & 11.3 & 61.7 & 0.98 & 0.61 & $\begin{array}{l}\text { Culley et al. } \\
(1981)\end{array}$ \\
\hline $\begin{array}{l}\text { W. arrhiza, } \\
\text { Bangladesh }\end{array}$ & $\begin{array}{l}\text { nutrient } \\
\text { not specified }\end{array}$ & 91.2 & 14.9 & - & - & - & - & - & - & $\begin{array}{l}\text { Majid et al. } \\
\text { (1992) }\end{array}$ \\
\hline $\begin{array}{l}\text { L. gibba, } \\
\text { USA }\end{array}$ & $\begin{array}{l}\text { High-nutrient }{ }^{3} \\
\text { lagoon }\end{array}$ & - & 36.3 & 6.3 & 15.5 & 10.1 & 31.8 & 1.81 & 2.60 & $\begin{array}{l}\text { Culley et al. } \\
\text { (1981) }\end{array}$ \\
\hline $\begin{array}{l}\text { L. gibba, } \\
\text { USA } \\
\end{array}$ & $\begin{array}{l}\text { Dairy cattle waste } \\
\text { lagoon }\end{array}$ & - & 38.5 & 3.0 & 16.4 & 9.4 & 32.7 & 1.00 & 1.60 & $\begin{array}{l}\text { Hillman \& } \\
\text { Culley (1978) } \\
\end{array}$ \\
\hline $\begin{array}{l}\text { L. minima, } \\
\text { USA }\end{array}$ & $\begin{array}{l}\text { Source not } \\
\text { specified }\end{array}$ & - & 31.0 & 2.0 & 14.0 & 10.0 & 42.2 & - & - & $\begin{array}{l}\text { Shireman } \\
\text { et al. }(1977)\end{array}$ \\
\hline $\begin{array}{l}\text { L. perpusilla, } \\
\text { Thailand }\end{array}$ & $\begin{array}{l}\text { Septage-fed earthen } \\
\text { pond }\end{array}$ & $\begin{array}{l}94- \\
94.3\end{array}$ & $\begin{array}{l}25.3- \\
29.3\end{array}$ & $\begin{array}{l}3.8- \\
4.5\end{array}$ & $\begin{array}{l}15.4- \\
17.6\end{array}$ & $\begin{array}{l}6.9- \\
7.6\end{array}$ & - & - & - & $\begin{array}{l}\text { Hassan \& } \\
\text { Edwards(1992) }\end{array}$ \\
\hline $\begin{array}{l}\text { S. oligorrhiza, } \\
\text { USA }\end{array}$ & $\begin{array}{l}\text { Dairy cattle waste } \\
\text { lagoon }\end{array}$ & - & 37.8 & 3.8 & 12.0 & 7.3 & 39.1 & 1.30 & 1.50 & $\begin{array}{l}\text { Hillman \& } \\
\text { Culley (1978) } \\
\end{array}$ \\
\hline $\begin{array}{l}\text { S. oligorrhiza, } \\
\text { USA }\end{array}$ & $\begin{array}{l}\text { Treated waste } \\
\text { water effluent }\end{array}$ & - & 32.7 & 6.3 & 20.3 & 13.5 & 27.2 & 1.49 & 1.15 & $\begin{array}{l}\text { Culley \& } \\
\text { Epps (1973) } \\
\end{array}$ \\
\hline $\begin{array}{l}\text { S. oligorrhiza, } \\
\text { USA }\end{array}$ & $\begin{array}{l}\text { Anaerobic swine } \\
\text { waste lagoon }\end{array}$ & - & 41.4 & 5.1 & 12.9 & 8.3 & 32.3 & 0.91 & 2.07 & $\begin{array}{l}\text { Culley \& } \\
\text { Epps (1973) }\end{array}$ \\
\hline $\begin{array}{l}\text { S. polyrhiza, } \\
\text { Thailand }\end{array}$ & $\begin{array}{l}\text { Septage-fed earthen } \\
\text { pond }\end{array}$ & 91.0 & 23.8 & 3.8 & 18.3 & 11.7 & 42.4 & - & - & $\begin{array}{l}\text { Hassan \& } \\
\text { Edwards (1992) }\end{array}$ \\
\hline $\begin{array}{l}\text { S. polyrhiza, } \\
\text { USA }\end{array}$ & $\begin{array}{l}\text { High-nutrient }{ }^{3} \\
\text { lagoon }\end{array}$ & - & 39.7 & 5.3 & 12.8 & 9.3 & 32.9 & 1.28 & 2.10 & $\begin{array}{l}\text { Culley et al. } \\
(1981)\end{array}$ \\
\hline $\begin{array}{l}\text { S. polyrhiza, } \\
\text { USA }\end{array}$ & $\begin{array}{l}\text { Dairy cattle waste } \\
\text { lagoon }\end{array}$ & - & 40.9 & 6.7 & 12.9 & 8.7 & 30.8 & 2.10 & 1.40 & $\begin{array}{l}\text { Hillman \& } \\
\text { Culley (1978) }\end{array}$ \\
\hline $\begin{array}{l}\text { S. punctata, } \\
\text { USA }\end{array}$ & $\begin{array}{l}\text { High-nutrient }{ }^{3} \\
\text { lagoon }\end{array}$ & - & 36.8 & 4.8 & 15.2 & 9.7 & 33.5 & 1.75 & 1.50 & $\begin{array}{l}\text { Culley et al. } \\
(1981)\end{array}$ \\
\hline
\end{tabular}


Haustein et al. (1992) reported a reduced meat production and a lower feed conversion ratios (g dry duckweed per g animal fresh weight) for pigs fed on duckweed whose protein content amounted to $23 \%$ and fibre content to $7.5 \%$ dry matter. Galkina et al. (1965), however, demonstrated a clearly positive effect on the weight gain of pigs when duckweed was added as a supplement to the normal diet. Further research is needed to show how duckweed can be used as the protein source in diets for pigs. Studies using fresh and dry duckweed and conventional (grain-based) and non-conventional feeds (for example, sugarcane juice or molasses) are urgently needed.

Observations in Bangladesh and Taiwan (Edwards et al. 1987) clearly revealed that ducks readily feed on fresh duckweed, often directly from the pond surface. However, chickens are preferably fed on dried duckweed. In general, small ammounts (2-25\% of total dry matter fed) of duckweed in the diet stimulate the growth of chickens, while higher additions (> 40\%) of duckweed tend to decrease weight gain (Haustein et al. 1988). There are reports of an increase in weight by $10-32 \%$ for chicken fed with small amounts of duckweed (2-5\%) in addition to their regular diet (Iqbal 1999). Shahjahan et al. (1981) obtained very good results with a $10 \%$ addition of Spirodela to a mixed chicken diet.

Duckweeds grown on nutrient-rich waters have the potential to be of high nutritional value particularly for the young or lactating ruminant and preliminary observations suggest that they might form the basis of a supplement to diets based on mature biomass such as crop residues, mature grass or pasture. Rusoff et al. (1980) reported that up to $75 \%$ of duckweed could be fed to Holstein cattle without affecting the taste of milk. The weight gain of calves fed with a mixture of duckweed (67\%) and silage of corn (33\%) showed a daily weight gain of $0.95 \mathrm{~kg}$, compared to only $0.5 \mathrm{~kg}$ weight gain when fed on a concentrate/ corn silage diet. Culley et al. (1981) calculated that a 3.1 ha surface area of duckweed cultivation could provide sufficient protein to feed 100 dairy cattle.

Taubaev and Abdiev (1973) reported an additional weight gain of up to $27 \%$ and $14 \%$ for ram and sheep, respectively, upon feeding the animals $0.5 \mathrm{~kg}$ /day Lemnaceae in addition to their regular diet. However, Leng et al. (1994) mentioned that the contribution of duckweed protein in ruminant nutrition is doubtful, as the duckweed protein is readily fermented by microorganisms in the rumen, and the amino acid supply to the animal is, thereby, minimized. It is likely that duckweed is initially used as a source of essential microbial nutrients to enhance the efficient fermentative digestion of straw in the rumen. Neverthless, feed technology research is needed to enhance the use of duckweed as direct protein source for ruminants.

Organic fertilizer: Duckweed can be used as an organic fertilizer in agriculture by direct land application or via composting. According to Lot et al. (1979), application of duckweed eventually contributed to a superior soil texture, including an improved water and cation exchange, and resulted in harvest of 4 crops of vegetables or corn, annually.

Biofuel: As mentioned earlier, there are conditions like temperature shifts due to seasons that can cause a morphological change of the normal fronds of several species of duckweed to a different structure, called turions. Turion formation can also be induced by transferring the fresh fronds from a nutrient-rich medium to tap water (Cheng \& Stomp 2009), addition of abscisic acid (ABA) in the growth medium (Perry \& Byrne 1969), or by " hot day-hot night "treatment of normal fronds of $30^{\circ} \mathrm{C}$ photo-temperature and $25^{\circ} \mathrm{C}$ dark-temperature and a photoperiod of 16 hours (Perry 1968). Because fronds have little lignin (Blazey \& McClure 1968), which would 
interfere with the digestion of the carbohydrate fraction (which amounts up to $70 \%$ in dry weight) of biomass, and turions have high starch content (60.1\% in dry mass), duckweed might also be suitable as an alternative source of bioenergy (Wang \& Messing 2012). Whereas cellulose is a crystalline, compact and structural compound resistant to biological attack and enzymatic degradation, starch is readily digested. Even though many advances have been made in the commercialization of cellulosic biomass (Gray et al. 2006), the cost of producing equal amounts of ethanol from cellulosic biomass is still much higher than production directly from starch (Wyman 2003). Therefore, growing attention is being devoted to use duckweeds as a source of carbon compounds and convert duckweed biomass into bio-ethanol (Cheng \& Stomp 2009).

Mosquito control: A positive effect of a duckweed cover on the decrease of mosquito larvae was reported for S. punctata (Furlow \& Hays 1972), L. minor (Angerilli \& Beirne 1980), Wolffia (Bentley 1910), and Spirodela (Culley \& Epps 1973). The authors suggested that a complete duckweed cover acts either as physical barrier and hinders the mosquito larvae from reaching the surface for oxygen uptake, or that the plants release compounds which are toxic to the larvae (Bentley 1910, Judd \& Borden 1980). A possibly reducing effect of duckweed on mosquito breeding may positively contribute to the acceptance of duckweed farming systems in areas where mosquitoes are a nuisance and a vector of serious human diseases like malaria or dengue (Iqbal 1999).

\section{Wastewater Treatment}

Solids are relatively easy to remove, what is most difficult to remove from the wastewaters are dissolved salts such as nitrates, phosphates, and other nutrients, and toxic metal ions and organic compounds (xenobiotic pesticides, etc.). In this context, the basic concept of a duckweed wastewater treatment system is to farm local duckweed on the wastewater requiring such treatment. Duckweed systems distinguish themselves from other wastewater treatment mechanisms in that they also produce a valuable, protein-rich biomass as a by-product.

Landolt and Kandeler (1987) reported that of all aquatic plants, duckweeds have the greatest capacity in assimilating the macro-elements $\mathrm{N}, \mathrm{P}, \mathrm{K}, \mathrm{Ca}, \mathrm{Na}$ and $\mathrm{Mg}$, however, this may not be supported by other literature sources. The data presented in Table 11 suggests that nutrient removal rates for duckweed are comparatively slower than for other aquatic plants and, therefore, longer retention times will be necessary to reduce nutrient concentrations to specific discharge limits. Gijzen and Khondker (1997) stated that despite contradictory data, it is an established fact that duckweed has a high nutrient removal efficiency.

Water hyacinth has been widely used for its extremely high nutrient uptake efficiency (Table 11). However, no economically attractive application of the harvested biomass has so far been identified. In addition, water hyacinth only grows efficiently in tropical climates.

Table 11. Daily nitrogen and phosphorus uptake rates by different floating aquatic macrophytes (DeBusk \& Reddy 1987, Reddy \& DeBusk 1985)

\begin{tabular}{lccccc}
\hline \multirow{2}{*}{ Plant } & \multicolumn{4}{c}{ Uptake $\left(\mathbf{g} / \mathbf{~ m}^{2} /\right.$ day) } \\
\cline { 2 - 3 } \cline { 5 - 6 } & \multicolumn{3}{c}{$\mathbf{N}$} & & \multicolumn{2}{c}{$\mathbf{P}$} \\
\cline { 2 - 3 } \cline { 5 - 6 } & Summer & Winter & & Summer & Winter \\
\hline Water hyacinth & 1.30 & 0.25 & & 0.24 & 0.05 \\
Water lettuce & 0.99 & 0.26 & & 0.22 & 0.07 \\
Pennywort & 0.37 & 0.37 & & 0.09 & 0.08 \\
Duckweed (S. polyrhiza) & \multicolumn{2}{c}{0.15} & & \multicolumn{3}{c}{0.03} \\
\hline
\end{tabular}


A specific comparison of duckweed with water hyacinth for wastewater treatment and biomass use is presented in Table 12.

Table 12. Comparison between duckweed and water hyacinth for wastewater treatment and biomass use

\begin{tabular}{|c|c|c|}
\hline Criterion & Duckweed & Water hyacinth \\
\hline $\begin{array}{l}\text { Tolerance to low } \\
\text { temperatures }\end{array}$ & Higher & $\begin{array}{l}\text { Lower, more restricted to warm } \\
\text { climates }\end{array}$ \\
\hline Nutrient uptake capacity & $\begin{array}{l}\text { - High, but smaller contact area } \\
\text { with the wastewater surface } \\
\text { - High tolerance to high nutrient } \\
\text { concentrations }\end{array}$ & $\begin{array}{l}\text { Higher, due to greater contact area } \\
\text { with the wastewater through root } \\
\text { hairs }\end{array}$ \\
\hline BOD removal efficiency & $\begin{array}{l}\text { - Lower, because of smaller surface } \\
\text { area for attached bacteria growth } \\
\text { and lower oxygen supply. } \\
\text { - Lower tolerance to high BOD } \\
\text { concentrations }(<200 \mathrm{mg} / \mathrm{l}) \\
\end{array}$ & $\begin{array}{l}\text { - Higher because of larger surface area } \\
\text { for attached bacteria growth and } \\
\text { higher oxygen supply to the root zone. } \\
\text { - Treatment of wastewater with very } \\
\text { high BOD concentrations }(>1000 \mathrm{mg} / \mathrm{l})\end{array}$ \\
\hline $\begin{array}{l}\text { Removal capacity of organic } \\
\text { xenobiotics and heavy metals }\end{array}$ & High & High \\
\hline Mosquito control & Positive & Negative \\
\hline Harvesting & $\begin{array}{l}\text { - Can be done manually and } \\
\text { mechanically }\end{array}$ & $\begin{array}{l}\text { - Complicated, because plants are } \\
\text { bulky and interconnected over } \\
\text { large distances } \\
\text { - Mechanical harvesting equipment } \\
\text { necessary }\end{array}$ \\
\hline $\begin{array}{l}\text { Nutrient profile (in } \% \text { dry } \\
\text { weight) when grown on } \\
\text { wastewater }\end{array}$ & $\begin{array}{l}\text { - Protein }(3045 \%) \\
\text { - Carbohydrate }(35 \%) \\
\text { - Fibre }(7-14 \%) \\
\text { - Fat }(3-7 \%) \\
\text { - High vitamin and mineral content }\end{array}$ & $\begin{array}{l}\text { - Protein }(10-25 \%) \\
\text { - Carbohydrate }(35-72 \%) \\
\text { - Fibre }(17-20 \%) \\
\text { - Fat }(1-3 \%)\end{array}$ \\
\hline Use of biomass & $\begin{array}{l}\text { - High quality feed supplement } \\
\text { for fish and other animals } \\
\text { - Land application } \\
\text { - Composting } \\
\text { - Methane \& ethanol fermentation } \\
\text { - Medicinal plant }\end{array}$ & $\begin{array}{l}\text { - Generally not consumed by fish } \\
\text { and other animals } \\
\text { - Land application } \\
\text { - Composting } \\
\text { - Biogas digestion } \\
\text { - Paper production }\end{array}$ \\
\hline $\begin{array}{l}\text { Water loss through } \\
\text { evapotranspiration (ET) }\end{array}$ & $\begin{array}{l}\text { Lower ET rates compared to } \\
\text { open water }(20-30 \% \text { reduction) }\end{array}$ & $\begin{array}{l}\text { Equal or increased ET rates } \\
\text { compared to open water }\end{array}$ \\
\hline
\end{tabular}

Duckweeds have been generally applied for the treatment of domestic or agricultural wastewaters. However, they may also be applied for the treatment of wastewaters arising from industries like petroleum, paper manufacturing, metal extraction, etc., which often contain toxic substances, notably, heavy metals (defined as elements with density $>5 \mathrm{mg} / \mathrm{cm}^{3}$ such as cadmium, chromium, copper, lead, mercury, zinc, etc.) and a variety of organic compounds. Lemnaceae can tolerate and accumulate high concentrations of heavy metals and organic compounds at accumulation factors ranging multiples of $10^{2}$ and $10^{5}$ (the accumulation factor for heavy metals being much higher at low metal concentrations). It is therefore, important that the plants are harvested at regular intervals to prevent the metals and organic compounds from settling on the sediments with the decaying duckweed. The duckweed cover or sections of it grown on wastewater contaminated with heavy metals and organic toxins should, under no 
circumstances be used anymore as animal feed or organic fertilizer, but rather be disposed off as safely as possible in bottom-sealed landfills. Alternatively, heavy metals can be regained from the plant tissues through low temperature caronization.

\section{General Considerations}

Duckweeds, the tiny aquatic plants, have a leaf-like body, called frond that performs photosynthesis. Fronds grow vegetatively and can increase biomass rapidly, lowering carbon dioxide in the air and reducing nitrogen and phosphorus in the water. Duckweeds have been fed to animals and fish to complement diets, largely to provide a protein of high biological value. Besides, the dormant phase of some duckweed species, called turions, is rich in starch, a suitable substrate for ethanol production. However, like a hidden treasure, duckweeds are unutilized in Nepal.

The growing awareness of water pollution and its threat to the ecology of a region and agriculture per se has also focussed attention on potential biological mechanisms for cleansing water of these impurities making it potable and available for reuse. There are thousands of derelict ponds polluted to eutrophication levels in Nepal alone that could potentially be cleansed of much of their pollutants and resurrected for duckweed aquaculture and fish farming. To resurrect derelict ponds, the approach might be to first establish duckweed aquaculture as a source of nutrients for terrestrial crop production (for example, mulches and organic fertilizer) and as the ponds' oxygen levels rise with harvesting of the crop, to introduce fish farming either in part of the pond or in adjacent (clean water) ponds.

Duckweeds will remain an unutilized/ underutilized resource unless the farmers are familiar with their economic and environmental values. There is vast need for popularization, market, and research support for the duckweed.

\section{References}

Alaerts, G. J., Md. M. Rahman and P. Kelderman. 1996. Performance analysis of a full-scale duckweedcovered sewage lagoon. Water Research 30(4): 843 - 852.

Angerilli, N. P. D. and B. P. Beirne. 1980. Influence of aquatic plants on colonization of artificial ponds by mosquitoes and their insect predators. Canadian Entomology 112: 793 - 796.

Ashbey, E. and E. Wangermann. 1949. Senescene and rejuvenation in Lemna minor. Nature 164: 187.

B. F. R. I. 1997. Research Progress Report: January - August, 1997. Freshwater Station, Bangladesh Fisheries Research Institute, Mymensingh, Bangladesh.

Baur, R. J. and D. H. Buck. 1980. Active research on the use of duckweeds in the culture of grass carp, tilapia, and freshwater prawns. Illinois Natural History Survey, RRI, Kinmundy. (polycopy).

Bentley, C. A. 1910. The natural history of Bombay malaria. Journal of Bombay Natural History Society 20: $392-422$.

Bhanthumnavin, K. and M. G. McGarry. 1971. Wolffia arrhiza a possible source of inexpensive protein. Nature 232: 495.

Blazey, E. B. and J. W. McClure. 1968. The distribution and taxonomic significance of lignin in the Lemnaceae. American Journal of Botany 55 (10): 1240 - 1245.

Cheng, J. J. and A. M. Stomp. 2009. Growing duckweed to recover nutrients from wastewaters and for production of fuel ethanol and animal feed. Clean - Soil, Air, Water 37 (1) : 17-26.

Cook, C. D. K. 1996. Aquatic and Wetland Plants of India. Oxford University Press, New Delhi.

Culley, D. D. and A. E. Epps. 1973. Use of duckweeds for waste treatment and animal feed. Journal of the Water Pollution Control Federation 45: 337 - 347. 
Culley, D. D. and R. W. Myers. 1973. Effect of Harvest Rate on Duckweed Yield and Nutrient Extraction in Dairy Waste Lagoons. US Department of Energy Final Report. School of Forestry and Wildlife Management, Louisiana State University, Baton Rouge.

Culley, D. D., E. Rejmenkova, J. Kvet and J. B. Frye. 1981. Production, chemical quality and use of duckweeds (Lemnaceae) in aquaculture, waste management, and animal feeds. Journal of the World Mariculture Society 12 (2): 27 - 49.

Culley, D. D., J. H. Gholson, T. S. Chisholm, L. C. Standifer and E. A. Epps. 1978. Water Quality Renovation of Animal Waste Lagoons Utilizing Aquatic Plants. US Environmental protection Agency, Oklahoma.

D W R P. 1997. Literature Review 1. Duckweed Research Project, Ministry of Fisheries and Livestock and DHN Consultants, Dhaka.

D W R P. 1998. Duckweed in Bangladesh. Duckweed Research Project, Ministry of Fisheries and Livestock and Royal Netherlands Embassy, Dhaka.

DeBusk, T. A. and K. R. Reddy. 1987. BOD removal in floating aquatic macrophyte-based wastewater treatment systems. Water Science and Technology 19: $273-279$.

Dinges, R. 1982. Natural Systems for Water Pollution Control. Van Nostrand Reinhold, New York.

Edwards, P. 1987. Use of terrestrial vegetation and aquatic macrophytes in aquaculture. In D. J. W. Moriarty and R. S. V. Pullin (eds.) Detritus and Microbial Ecology in Aquaculture. ICLARM Conference Proceedings No. 14, Manila. pp. 311 - 335.

Edwards, P. 1990. An alternative excreta - reuse strategy for aquaculture: the production of high protein feed. In P. Edwards and R. S. V. Pullin (eds.) Wastewater - fed Aquaculture. Environmental Sanitation Information Center, Asian Institute of Technology, Bangkok. pp. 209 - 221.

Edwards, P., C. Polprasert and K. L. Wee. 1987. Resource Recovery and Health Aspects of Sanitation. Asian Institute of Technology Report no. 205, Bangkok.

Edwards, P., M. S. Hassan, C. H. Chao and C. Pacharaprakiti. 1992. Cultivation of duckweeds in septage - loaded earthen ponds. Bioresource Technology 40: 109 - 117.

Furlow, B. M. and K. L. Hays. 1972. Some influences of aquatic vegetation on the species and number of Culicidae (Diptera) in small pools of water. Mosquito News 32: 595 - 599.

Gaigher, I. G. and R. Short. 1986. An evaluation of duckweed (Lemnaceae) as a candidate for aquaculture in South Africa. In R. D. Wamsley and J. G. Wan (eds.) Aquaculture 1980. Report Series no 15, CSIRO, Canberra. pp. $81-90$.

Galkina, N. V., D. A. Abdullaev and V. L. Zacharova. 1965. Biological feed features of duckweeds. Uzbekistan Biological Journal 3: 44 - 47.

Gijzen, H. J. and M. Khondker. 1997. An overview of the ecology, physiology, cultivation and applications of duckweed. Inception Report. Annex 1. Literature Review. Duckweed Research Project, Dhaka.

Gopal, B. and Chamanlal. 1991. Distribution of aquatic macrophytes in polluted water bodies and their bio-indicator value. Verhandlungen des Internationalen Vereins fur Limnologie 24: 2125 - 2129.

Gray, K. A., L. Zhao and M. Emptage. 2006. Bioethanol. Current Opinion Chemical Biology 10 (2) : 141 $-146$.

Guha, R. 1997. Duckweeds. Envis Newsletter (March 1997): 5 - 9 (Indian Institute of Science, Bangalore).

Hasan, M. R. and R. Chakraborti. 2009. Use of Algae and Aquatic Macrophytes as Feed in Small-scale Aquaculture: A Review. Food and Agriculture Organization of the United Nations, Rome.

Hassan, M. S. and P. Edwards. 1992. Evaluation of duckweed (Lemna perpusilla and Spirodela polyrrhiza) as feed for Nile tilapia (Oreochromis niloticus). Aquaculture 104: 315 - 326.

Haustein, A. T., R. H. Gillman, P. W. Skillicorn, V. Guevara, F. Dias, V. Vergara, A. Gastanaduy and J. B. Gillman. 1992. Compensatory growth in broiler chicks fed on Lemna gibba. British Journal of Nutrition 68 (2): 329 - 335.

Haustein, A. T., R. H. Gillman, P. W. Skillicorn, V. Vergara, V. Guevara and A. Gastanaduy. 1988. Duckweed, a useful strategy for feeding chickens: performance of layers fed with sewage - grown Lemnaceae species. Poultry Science 69: 1835 - 1844.

Hillman, W. S. and D. D. Culley. 1978. The uses of duckweed. American Scientist 66: $442-451$. 
Hutchinson, G. E. 1975. A Treatise on Limnology; Vol. 3 : Limnological Botany. John Wiley \& Sons, New York.

Iqbal, S. 1999. Duckweed Aquaculture: Potentials, Possibilities and Limitations for Combined Wastewater Treatment and Animal Feed Production in Developing Countries. SANDEC Report No. 6/99. Department of Water \& Sanitation in Developing Countries, Swiss Federal Institute for Environmental Science \& Technology, Duebendorf.

Islam, A. K. M. N. and M. Khondker. 1991. Preliminary limonological investigations of some polluted waters covered by duckweeds. Bangladesh Journal of Botany 20 : 73-75.

Judd, G. J. R. and J. H. Borden. 1980. Oviposition deterrents for Aedes aegypti in extracts of Lemna minor. Journal of Entomological Society $77: 30$ - 33.

Khondker, M., A. K. M. N. Islam and A. D. Makhnun. 1994. Lemna perpusilla screening on habitat limonology. Bangladesh Journal of Botany 23 : 91 - 106.

Khondker, M., A. K. M. N. Islam and N. Nahar. 1993. A preliminary study on the growth rate of Spirodela polyrhiza. Dhaka University Journal of Biological Sciences 2 : 197 - 200.

Koirala, U. 2015. Ecological Study of Wetland Macrophytes Occurring in Morang District of Nepal. Ph. D. Thesis, Tribhuvan University, Kathmandu.

Koirala, U., S. Jha and B. Niroula. 2011. Effect of different water pH on growth of some free-floating macrophytes at Biratnagar, Nepal. Geobios 38 (2-3) : 212 - 213.

Landolt, E. 1986. The family of Lemnaceae - A monographic Study : Morphology, Karyology, Ecology, Geographic distribution, Systematic position, Nomenclature, Descriptions, Vol. $2 . \quad$ Veroffentlichungen des Geobotanisches Institute der Eidgenossische Technische Hochschule, Stiftung Ruebel, Zurich.

Landolt, E. 2006. Duckweed. In Flora of North America North of Mexico, Vol. 22. Flora of North America Editorial Committee, New York and Oxford.

Landolt, E. and R. Kandeler. 1987. The family of Lemnaceae - A Monographic Study : Phytochemistry, Physiology, Application and Bibliography, Vol. 4. Veroffentlichungen des Geobotanisches Institut der Eidgenossische Technische Hochschule, Stiftung Ruebel, Zurich.

Leng, R. A. 1999. Duckweed: A Tiny Aquatic Plant with Enormous Potential for Agriculture and Environment. Food and Agriculture Organization of the United Nations, Rome.

Leng, R. A., J. H. Stambolie and R. Bell. 1994. Duckweed - a potential high-protein feed resource for domestic animals and fish. In Proceedings of the $7^{\text {th }}$ Animal Science Congress of the Asian Australasian Association of Animal Production Societies (AAAP) Conference. Indonesian Society of Animal Science, Jakarta. pp. 103-114.

Lot, A., A. Novelo and A. Quiroz, 1979. The chinampa : an agricultural system that utilizes aquatic plants. Journal of Aquatic Plant Management 17 : 74 - 75.

Luond, A. 1980. Effects of nitrogen and phosphorus upon the growth of some Lemnaceae. In E. Landolt (ed.) Biosystematic Investigations in the Family of Duckweeds (Lemnaceae). Veroffentlichungen des Geobotnisches Institute der Eidenossische Technische Hochschule, Stiftung Ruebel, Zurich. pp. 118141.

Majid, F. Z., R. Khatun, N. Akhtar and A. S. M. A. Rahman. 1992. Aquatic weeds as a source of protein in Bangladesh. Bangladesh Journal of Scientific and Industrial Research $27: 103-111$.

Nikolskij, G.V. and B.V. Verigin. 1966. The basic biological characteristics of white amur and bighead and their acclimatization in the water reservoirs of our country. In Herbivorous Fish. Piscevaja Promyslennost, Moscow. pp. 30-40.

Ogburn, D. M. and N. J. Ogburn. 1994. Use of duckweed (Lemna sp.) grown in sugarmill effluent for milkfish, Chanos chanos Forskal, production. Aquaculture and Fisheries Management 25 : 497 503.

Perry, T. O. 1968. Dormancy, turion formation, and germination by different clones of Spirodela polyrrhiza. Plant Physiology 43 : 1866 - 1869.

Perry, T. O. and O. R. Byrne. 1969. Turion induction in Spirodela polyrrhiza by abscisic acid. Plant Physiology $44: 784-785$.

Reddy, K. R. and W. F. DeBusk. 1984. Growth characteristics of aquatic macrophytes cultured in nutrientenriched water : 1. Water hyacinth, water lettuce, and pennywort. Economic Botany 38 : 229 - 239. 
Reddy, K. R. and W. F. DeBusk. 1985. Textbook of Fish Genetics and Biotechnology. Indian Council of Agricultural Research, New Delhi.

Rejmankova, E. 1975. Comparison of Lemna gibba and Lemna minor from the production viewpoint. Aquatic Botany 1 : 423 - 427.

Rusoff, L. L., E. W. Blakeney and D. D. Culley. 1980. Duckweeds (Lemnaceae family) : a potential source of protein and amino acids. Journal of Agricultural and Food Chemistry $28: 848-850$.

Said, M. Z., D. D. Culley, L. C. Standifer, E. A. Epps, R. W. Myers and S. A. Bonney. 1979. Effect of harvest rate, waste loading \& stocking density on the yield of duckweeds. Proceedings of the World Mariculture Society 10 : 769 - 780.

Shahjahan, M., A. H. Khan, N. Akhtar, A. S. M. A. Rahman and F. Z. Majid. 1981. Use of aquatic weeds and algae as poultry feed. Proceedings $2^{\text {nd }}$ Annual Conference, Livestock. Bangladesh Agriculture University, Mymensingh. pp. 272-278.

Sheh - May, T., P. C. Boyce, T. M. Upson, D. Barabe, A. Bruneau, F. Forest and J. S. Parker. 2004. Intergeneric and intrafamilial phylogeny of subfamily Monosteroideae (Araceae) revealed by chloroplast sequences. American Journal of Botany 91 : 490 - 498.

Shireman, J. V., D. E. Colle and R. W. Rottmann. 1977. Intensive culture of grass carp, Ctenopharyngodon idella in circular tanks. Journal of Fish Biology 11 : 267 - 272.

Skillicorn, P., W. Spira and W. Journey. 1993. Duckweed Aquaculture : A New Aquatic Farming System for Developing Countries. The World Bank, Washington, D.C.

Stapp, W. B. and M. K. Mitchell. 1995. Field Manual for Global Low-cost Water Quality Monitoring. Green Office, Michigan.

Sutton, D. L. and W. H. Ornes. 1975. Phosphorus removal from static sewage effluent using duckweed. Journal of Environmental Quality $4: 367$ - 370.

Taubaev, T. T. and M. Abdiev. 1973. Duckweeds of Water Reservoirs in Uzbekistan and their Use in Agriculture. Fan, Taskent.

Upadhyay, B. P., S. Jha, U. Koirala and B. Niroula. 2011. Inventory of ten aquatic habitats of Biratnagar township, Nepal. Geobios 38 (4) : 283 - 288.

Van der Does, J. and F. J. Klink. 1991. Excessive growth of Lemnaceae and Azolla in ditches observed by false colour teledetection. Verhandlungen des Internationalen Vereins fur Limnologie 24 : 2683 2688.

Vroon, R. and B. Weller. 1995. Treatment of Domestic Wastewater in a Combined UASB - reactor Duckweed Pond System. Landbouwuniversiteit, Wageningen.

Wang, W. and J. Messing. 2012. Analysis of ADP - glucose pyrophosphorylase expression during turion formation induced by abscisic acid in Spirodela polyrhiza (greater duckweed). BMC Plant Biology 12 : $274-290$.

Wangermann, E. and E. Ashbey. 1950. Morphogenesis in Lemna minor. Proceedings Linnean Society of London 162 : 10 - 13.

Wolff, P. and E. Landolt. 1994. Spread of Lemna turionifera (Lemnaceae), the red duckweed in Poland. Fragmenta Floristica et Geobotanica 39 : 439 - 451.

Wyman, C. E. 2003. Potential synergies and challenges in refining cellulosic biomass to fuels, chemicals, and powder. Biotechnological Progress 19 (2) : $254-262$.

Zaher, M., N. N. Begum, M. E. Hoq and A. K. A. Bhuiyan. 1995. Suitability of duckweed, Lemna minor as an ingredient in the feed of tilapia, Oreochromis niloticus. Bangladesh Journal of Zoology 23 : 7 12.

Zirschky, J. and S. C. Reed. 1988. The use of duckweed for wastewater treatment. Journal of the Water Pollution Control Federation 60 : $1254-1258$.

Zutshi, D. P. and K. K. Vass. 1973. Ecology of macrophytic vegetation of Kashmir lake. In C. R. Varshney and J. Rzoska (eds.) Aquatic Weeds in S. E. Asia. Junk, The Hague. pp. 141-146. 